Department of Health \& Human Services National Institutes of Health

\title{
ASEE ERC workshop Bioengineering training and research support from NIH
}

William Heetderks, M.D., Ph.D.

Associate Director for Science Programs

National Institute for Biomedical Imaging and

Bioengineering 


\section{Topics for today}

- NIH overview

- Training opportunities

- Research opportunities

- References and links 


\section{The Broad Reach of the NIH}



NIH is an institution

(Intramural Research)

6,000 scientists

$10 \%$ of NIH budget



NIH supports institutions \& people (Extramural Research)

$>4,000$ institutions

$>300,000$ scientists \& research personnel

$\sim 85 \%$ of the NIH budget 


\section{NIH Grant Statistics}

\section{Fiscal Year 2010}

- 88,000 applications received (all mechanisms)

- 240 Review Officers organized 1,600 meetings with 18,000 reviewers

- Over 62,000 research grants reviewed






\section{NIH is organized into:}

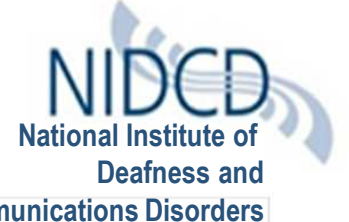

- NIMHD

National Institute on Minority Health and Health Disparities

\section{NIAAA National Institute on Alcohol}

National Heart

Lung and Blood Institute

National Institute

of Allergy and

Infectious Diseases

NATIONAL INSTITUTE

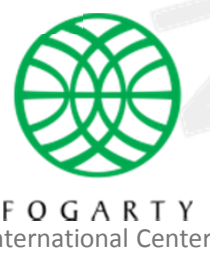

(2) Eunice Kennedy, Ofliviver

NIDA 11]

National Institute of

Environmental Health Sciences
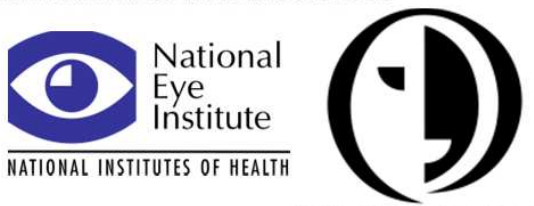

National Institute of Dental and Craniofacial Research

\section{Institutes \& Centers (IC) each with different:}
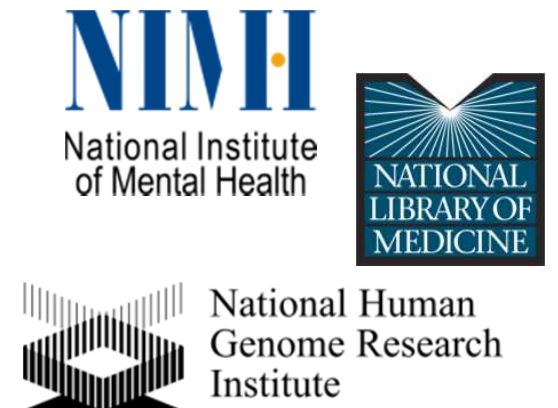

- missions and priorities

- budgets

- ways of deciding which grants to fund



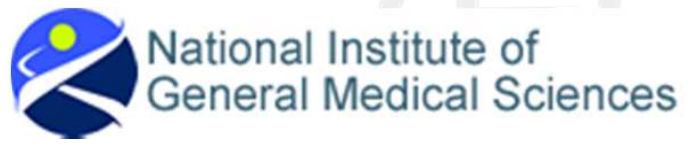

NIDDK (马)

National Institute of Diabetes and Digestive and Kidney Diseases

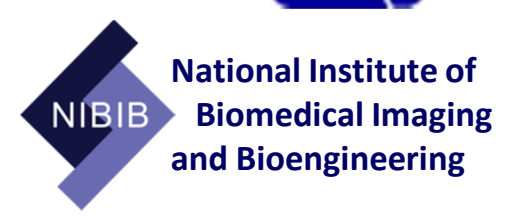

National Center for Research Resources

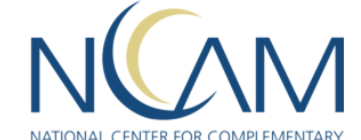

NATIONAL CENTER FOR COMPLEMENTABY



NATIONAL INSTITUTE ON AGING

National Institutes of Health 


\section{NIH FY10 Budget}

$\mathrm{NIH}$ Divides most of its investment according to the interests of the component parts (i.e. Institutes or Centers), with $<4 \%$ ) allocated to trans-NIH initiatives.






\section{Research Project Grants (RPGs): The Mainstay of NIH Sponsored Research}

Awards as percentage of all research grants.



Research Project Grants (RPGs) include R00, R01, R03, R15, R21, R22, R23, R29, R33, R34, R35, R36, R37, R55, R56, RL1, RL5, RL9, P01, P42, PN1, UC1, UC7, U01, U19, U34, DP1, DP2, RL1, RL2, RL5, RL9. More info available at: $\underline{\text { http://www.report.nih.gov }}$ 


\section{Research Project Grants (RPGs) Size}

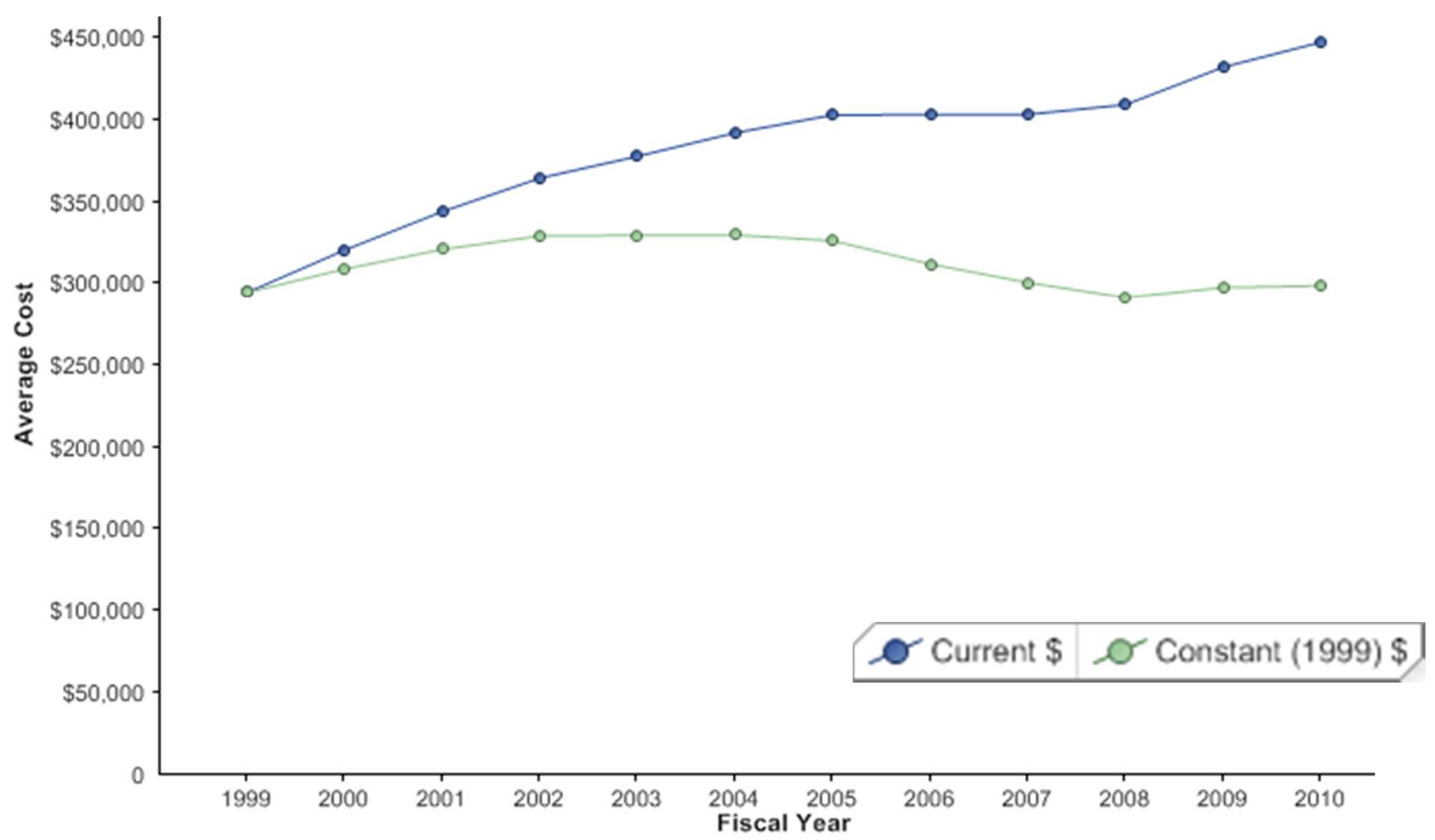

-Research Project Grants (RPGs) include R00, R01, R03, R15, R21, R22, R23, R29, R33, R34, R35, R36, R37, R55, R56, RL1, RL5, RL9, P01, P42, PN1, UC1, UC7, U01, U19, U34, DP1, DP2, RL1, RL2, RL5, RL9. 


\section{NIH Funding Supports Scientists at Every Career Stage}

\section{Approx. Stage of Research Training and Development}

Mechanism of Support

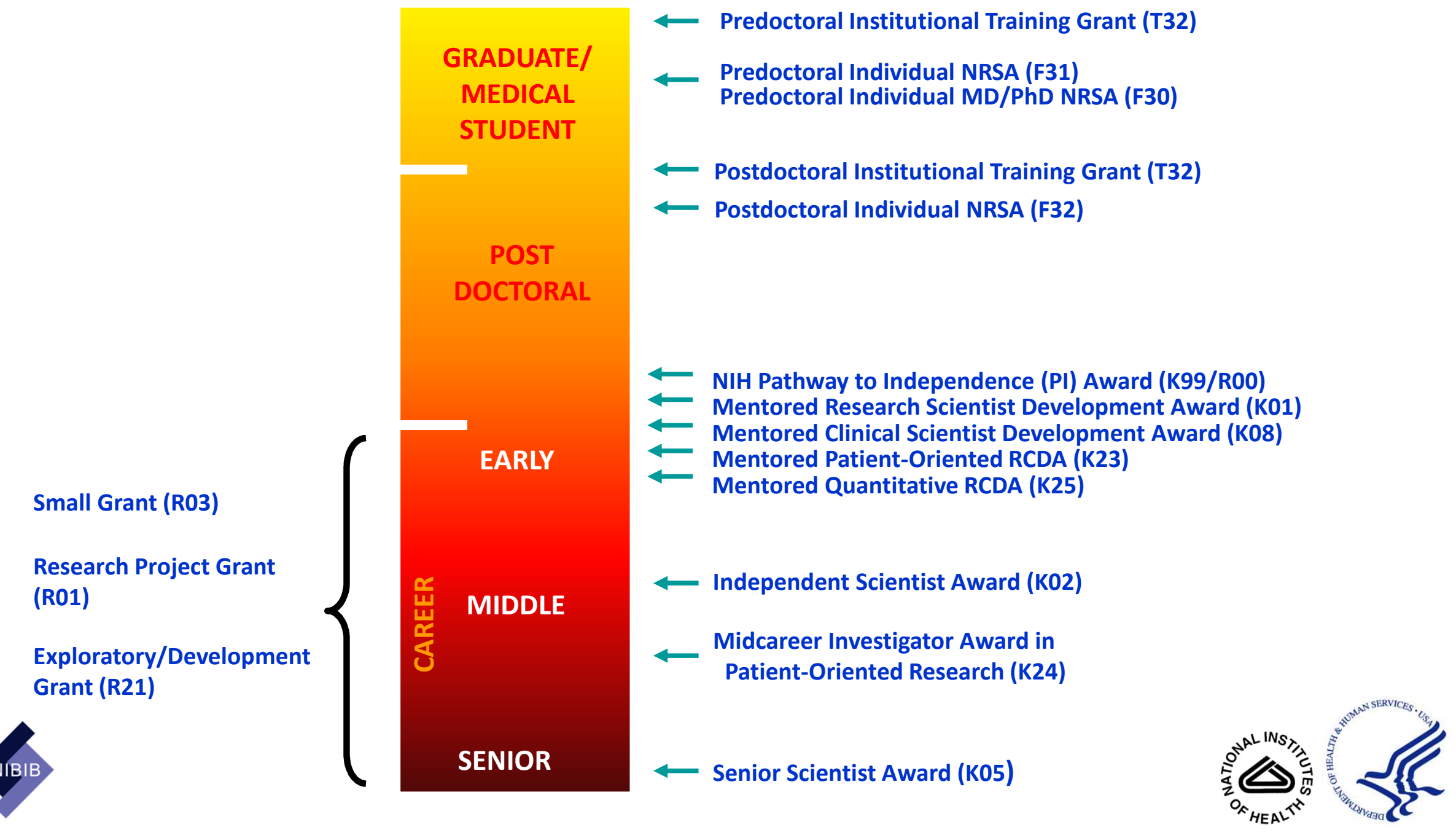


TRAINING 


\section{Team-Based Design Projects (R25)}

- Capstone design courses at BME departments

- Open-ended biomedical design projects

- Team-based approach

- Clinical immersion

- Emphasize translation of biomedical devices, including industrial design, regulation and commercialization concepts

- New or existing programs

- \$20k for parts and supplies, machining, didactic development, speaker expenses, patent searches, etc

- \$20k for student stipends only for programs with a clinical immersion period in the summer

http://grants.nih.gov/grants/guide/pa-files/par-10-140.html 


\section{Design by Biomedical Undergraduate Teams (DEBUT) Challenge}

$\square$ Open to undergraduate students

$\square$ Team-based design projects in three categories:

- Diagnostic Devices/Methods

- Therapeutic Devices/Methods

- Technology to Aid Underserved Populations and Individuals with Disabilities.

$\square$ Winners in each category receive:

$-\$ 10,000$ prize

- Up to $\$ \mathbf{2 , 0 0 0}$ in travel costs to attend award ceremony at BMES Annual Meeting

$\square$ Entry deadline: May 26, 2012; Winners announced: July 31, 2012 http://debut.challenge.gov/ 


\section{Institutional Training}

Disciplinary


Multidisciplinary
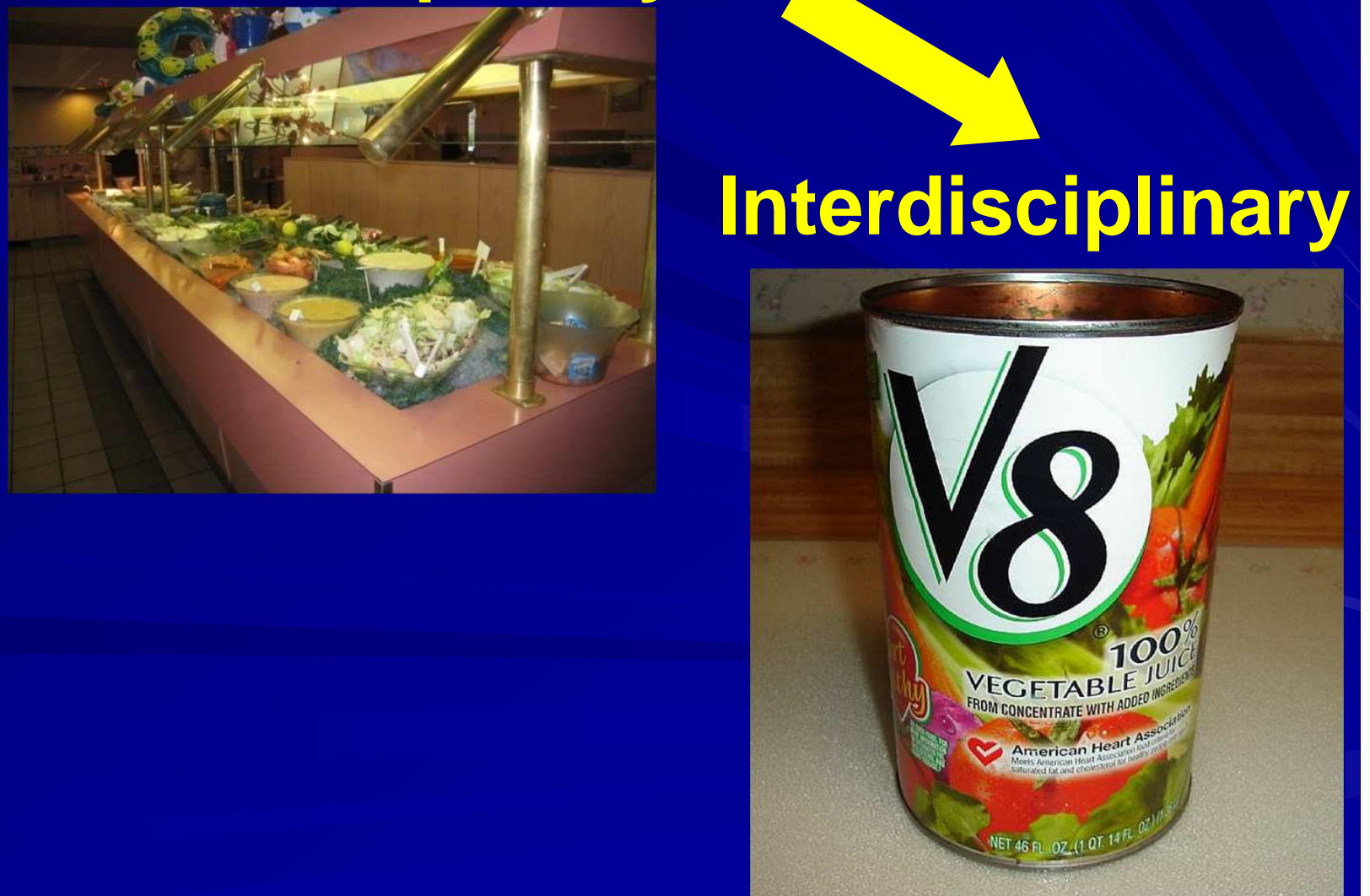


\section{Integrative Program in Complex Biological Systems (UCSF)}

USF University of California, San Francisco

This HHMI-NIBIB Interfaces Program, using Boot Camps in computation and molecular biology and Team Challenges in biomedical imaging. molecular biology, and systems biology, trains students in the understanding and engineering of complex biological systems from the molecular to the organismal level.
Challenge 1 - Design and build a fluorescent microscope from component parts, using it to analyze an unknown spectrum.

Challenge 2-Given a set of yeast samples, deduce what molecular perturbation occurred prior to their demise, constructing genomic microarrays and using bioinformatic tools.

Challenge 3 - Design a novel synthetic biological behavior using literature-derived genetic elements and specifying the system at the DNA level. 


\section{Biomedical Imaging and Informational Sciences (UPenn)}



This HHMI-NIBIB Interfaces program, by integrating medical school and imaging coursework and dually mentoring students with basic and clinical mentors, produces translational scientists who understand the medical basis of disease and have the technological know-how to develop new imaging methods for detection, diagnosis, and treatment.
Howard Hughes Medical Institute(HHMI) and

National Institute of Biomedical Imaging \& Bioengineering(NIBIB) Interfaces Initiative at the University of Pennsylvania

WTIII PHD TRAINING IN
BIOMEDICAL IMAGING \& INFORMATIONAL SCIENCE HHMI INTERFACES SCHOLARS






\section{Research Education Programs for Residents and Fellows (R25)}

Integrates education programs of Radiology and other clinical departments and supports residents and fellows in radiology and other NIBIB-relevant residency programs as clinician-scientists.

$\square$ Parent program based in radiology department.

$\square$ Program participants from radiology and other residency programs, including cardiology, neurology, oncology, orthopaedics, ophthalmology, and surgery.

$\square 12$ or 24 month support

$\square>75 \%$ effort

$\square \$ 70 \mathrm{k} /$ participant, $\$ 10 \mathrm{k}$ expenses, $\$ 1 \mathrm{k}$ travel

$\square 2$ participants/yr 


\section{New and Early-Stage Investigators}

New Investigator - Applicant has not previously been a PD/PI on a significant NIH independent research award.

Early-Stage Investigator - New Investigator within 10 yrs of completing their terminal degree or medical residency.

Peer reviewers will focus more on the approach of early-stage investigators than their track record and expect less preliminary data

\section{NIBIB Edward C. Nagy New Investigator Policy}

- $5 \%$ payline relaxation for New Investigators

- Only for R01 applications 


\section{Career Development Programs}

Mentored support for basic and clinical investigators who are transitioning to independence, changing their research focus, or need protected research time.

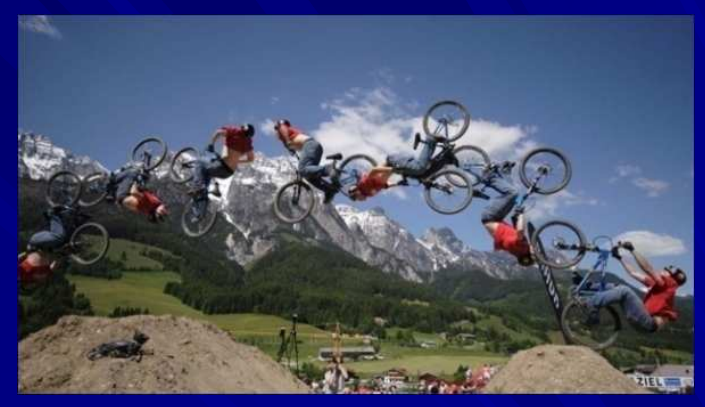

$\square$ K99/R00 - Pathway to Independence Award

$\square$ K01 - Research Scientist Development Award

- K25 - Quantitative Scientist Development Award

$\square$ K08 - Clinical Scientist Development Award $\square$ K23 - Patient-Oriented Development Award

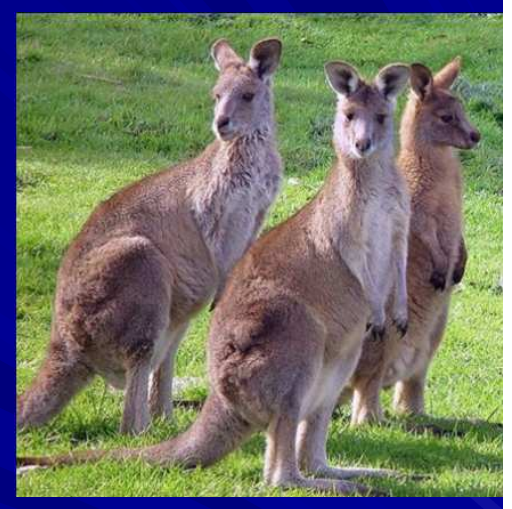

Receipt Dates: Feb/June/Oct 12 (Mar/July/Nov resubmissions)

K Kiosk: http://grants1.nih.gov/training/careerdevelopmentawards.htm 


\section{Pathway to Independence Program (K99/R00 - Kangaroo Award)}

$\checkmark$ US citizen/permanent residents or non-citizens on visas

$\checkmark$ No more than 5 years of postdoctoral experience

$\checkmark$ Must be in dependent position

K99 Dependent Phase

- 1-2 yrs mentored postdoctoral support

- \$50K salary, \$20K research costs + 8\% F\&A

R00 Independent Phase

- 3 yrs -- contingent upon securing an independent research/faculty position

- $\$ 249 / y r$ total cost with full F\& A 


\section{Pathway to Independence Program (K99/R00 - Kangaroo Award) - cont.}

- NIBIB committed to 5 K99/R00 awards/yr

- 23 awards since 2007

- 9 successful transitions to R00 phase

Matthew J Allen, PhD Assistant Professor

Department of Chemistry, Wayne State University "Increasing the Utility of Contrast Agents for MRI"






\section{NIH Director's Early Independence Award (DP5)}

$\square$ Inspired by programs at Carnegie, UCSF, Whitehead, and other institutions.

$\square$ Helps exceptional MDs/PhDs omit traditional postdoctoral training and move directly into mentored research positions.

$\square$ Reduces the time it takes young scientists to launch independent research careers.

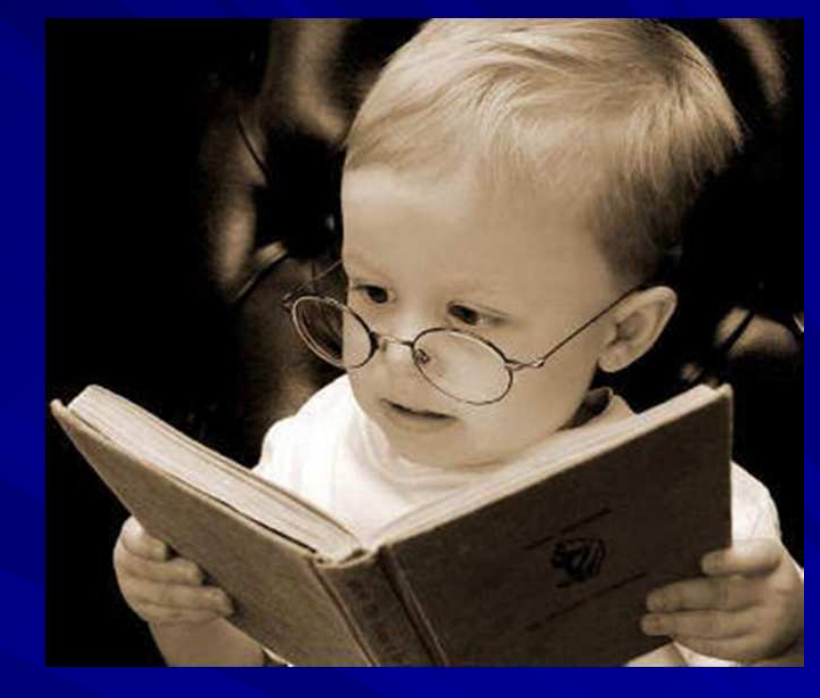

NIH Director's

Early Independence

Award Program

Receipt date: January 30, 2012 


\section{Mentored Quantitative Research Development Award (K25)}

- Early-career investigators with quantitative backgrounds who are changing their focus to biomedical research.

- Quantitative (e.g., mathematics, statistics, economics, computer science) and engineering backgrounds

Brian S Caffo, PhD Associate Professor

Department of Biostatistics, Johns Hopkins University "Mentored Training Program in Quantitative Medical Imaging"

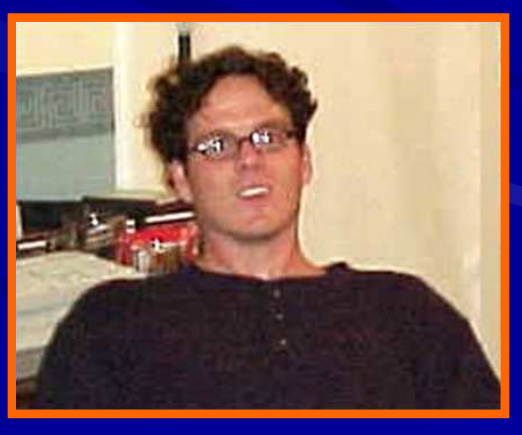




\section{Research Scientist Development Award (K01)}

- Early-career investigators with quantitative backgrounds who are transitioning to research independence

- Career path redirection or other institutespecific requirement may apply- check with Program Director before preparing application

Ann-Marie Broome, Ph.D.

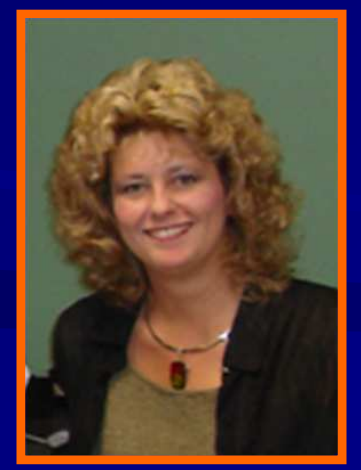

Research Assistant Professor

Case Western Reserve University

"Imaging Complex Molecular Signatures in Cancer" 
RESEARCH 


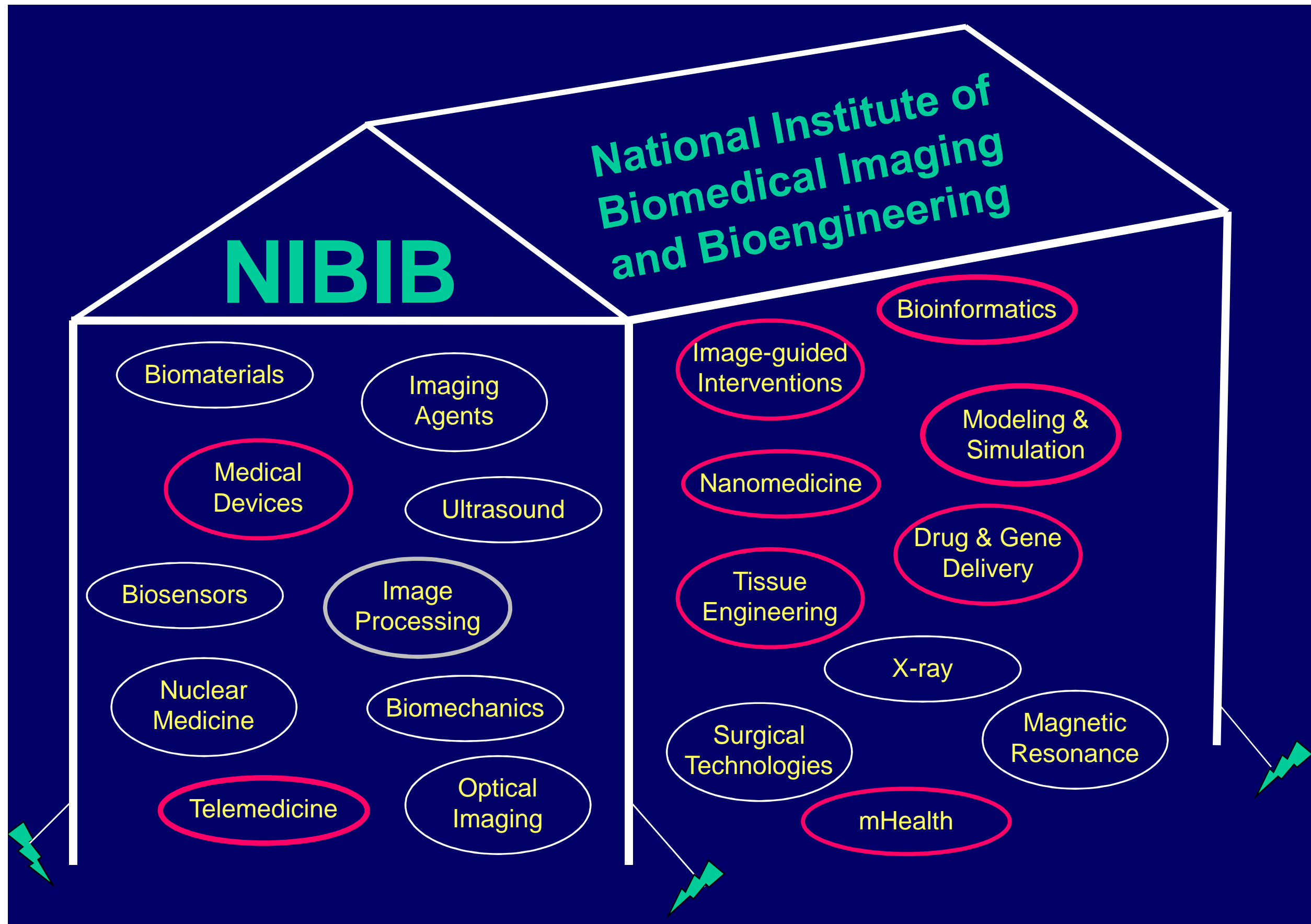

HHMI-NIBIB Public Forum 


\section{DMR measurements}

NIBIB R01 Weissleder: Molecular Analysis of Cells at the Point-of-Care

\section{Sample collection}

a

Monodisperse $(\sim 38 \mathrm{~nm})$

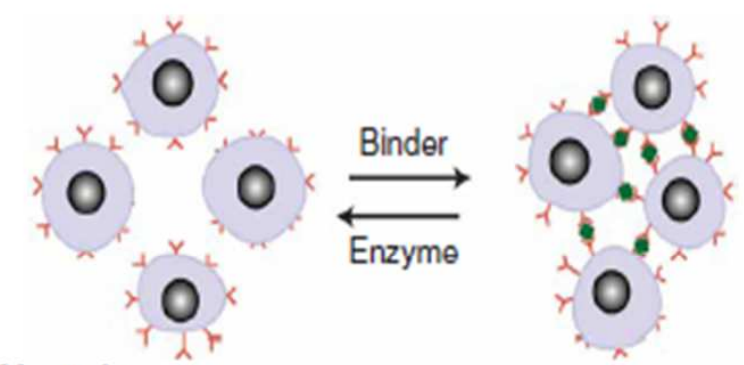

Magnetic

nanoparticles
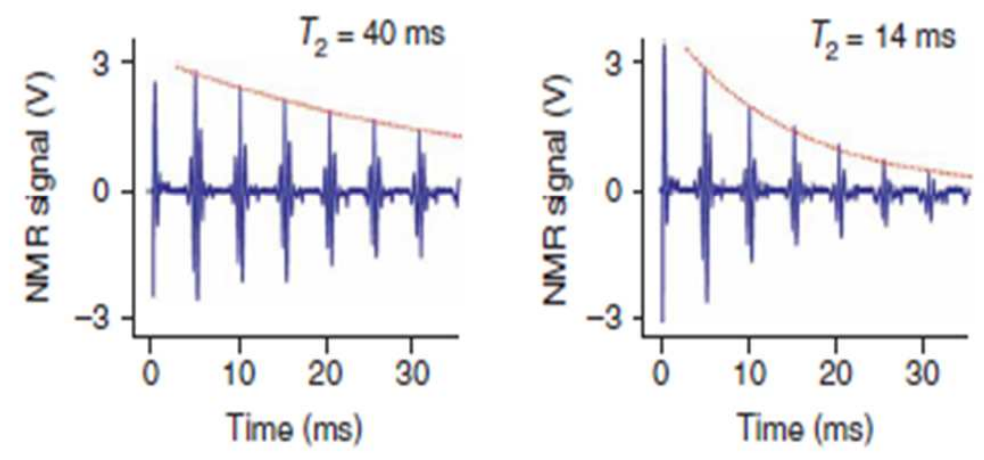

Nature Nanotech. 2010;5(9):660-5

3. On chip measurement

b

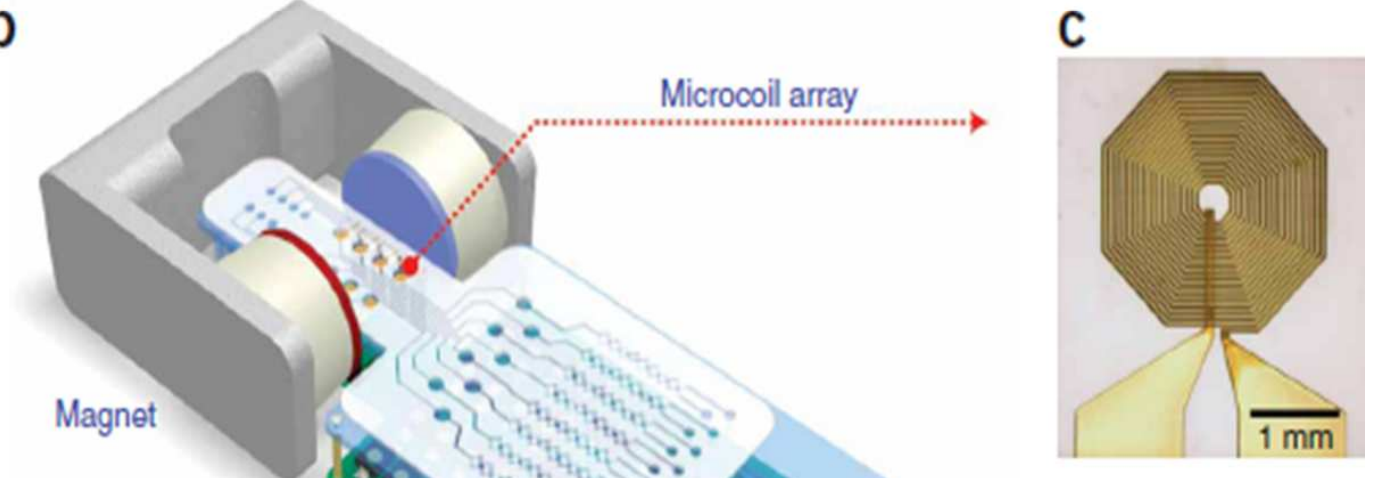

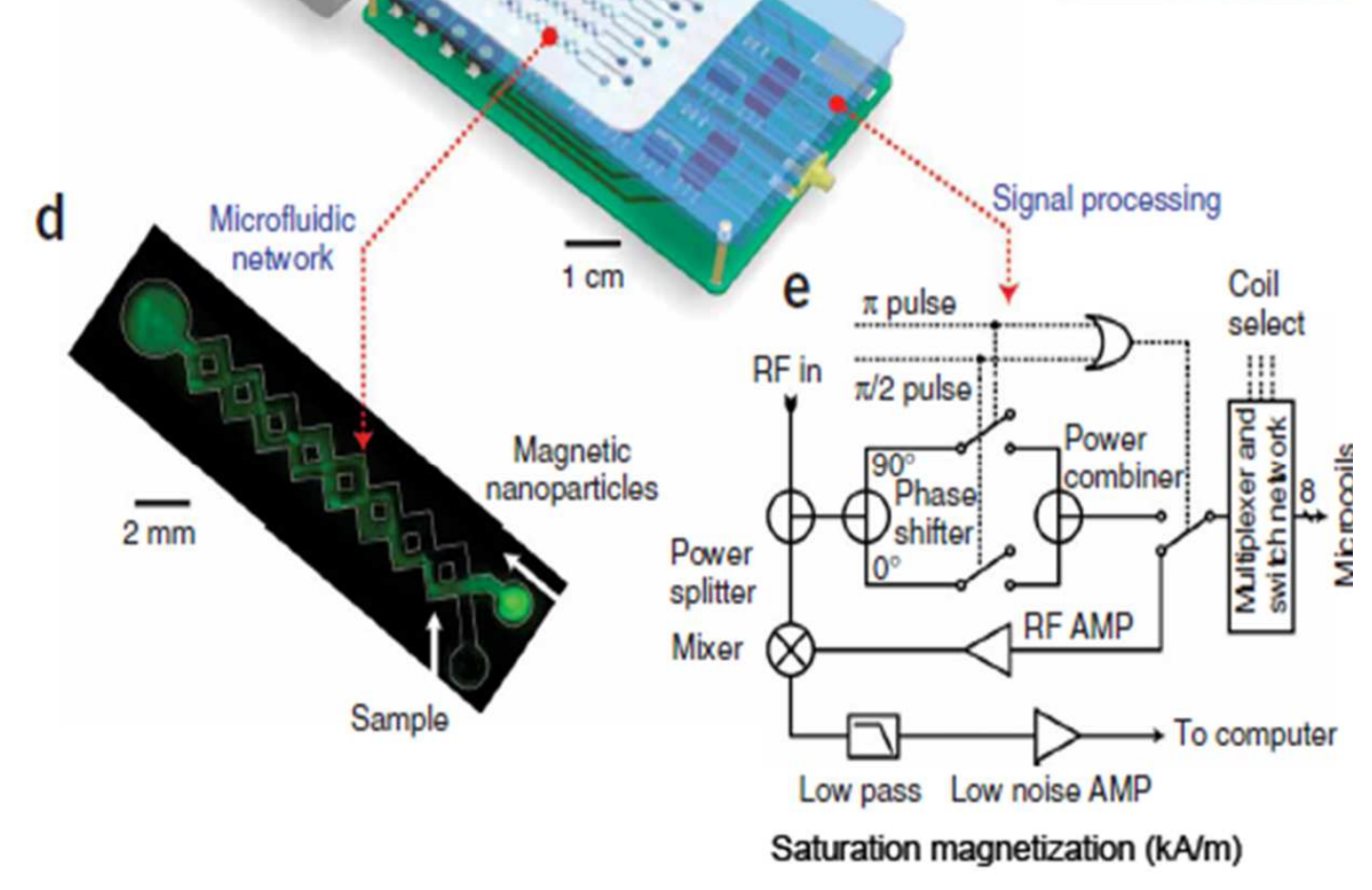




\section{World smallest NMR}

NIBIB R01 Weissleder: Molecular Analysis of Cells at the Point of Care

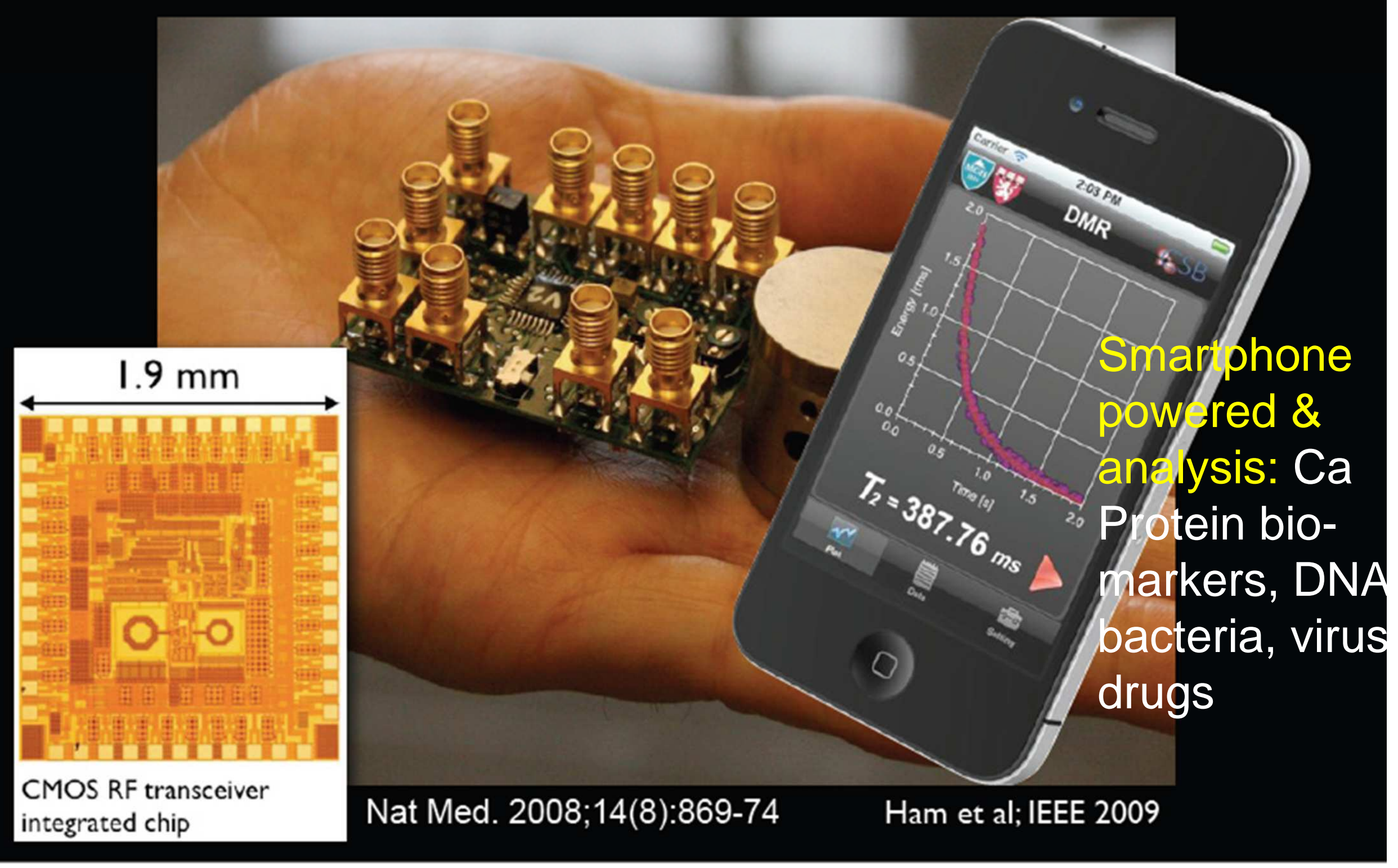




\section{Game changing technology}

Ca Dx: DMR Accuracy 96\% vs Biopsy Accuracy 84\%
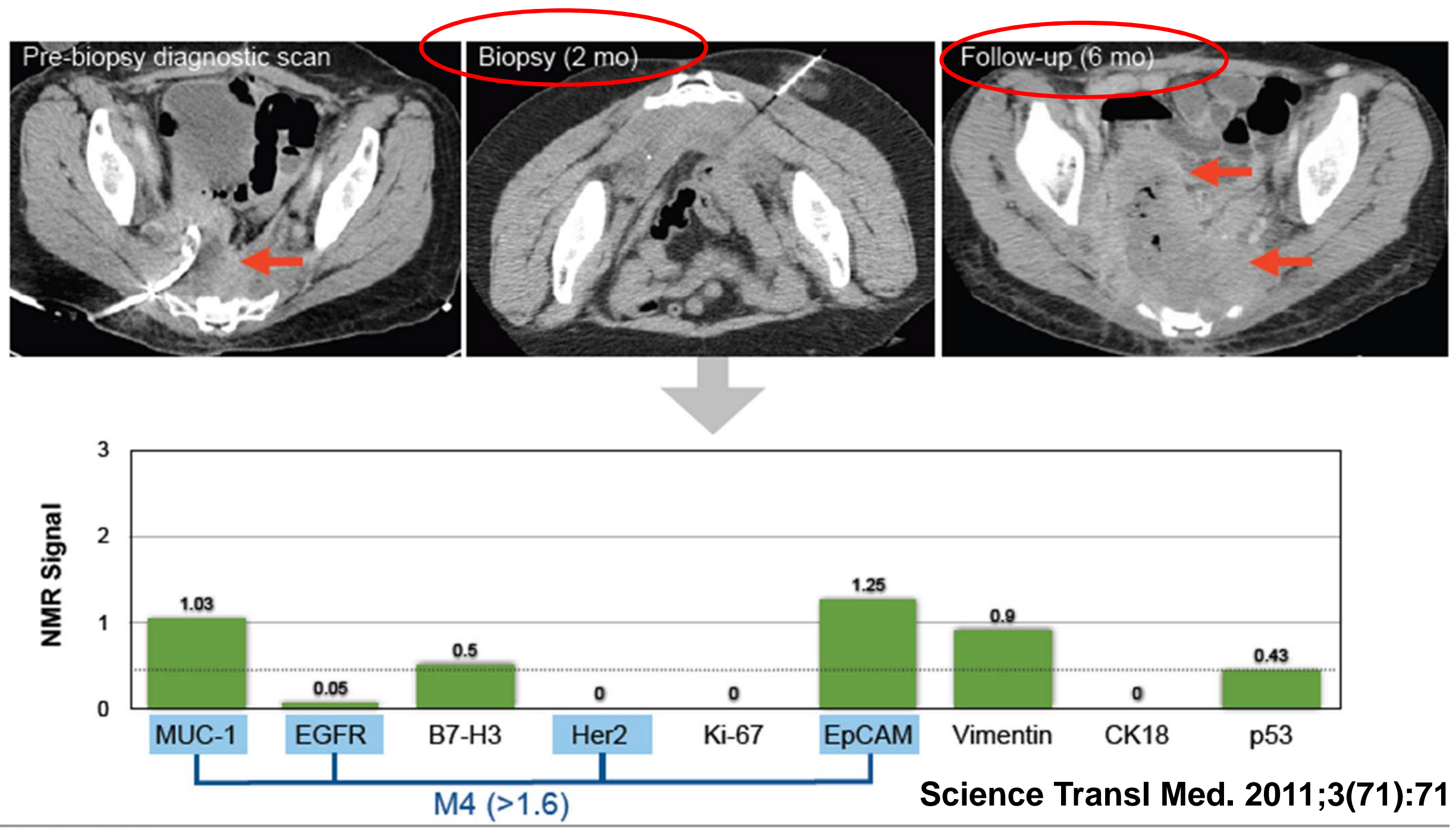


\section{Bioengineering support at $\mathrm{NIH}$}

- FY 2010 - \$3,166M

- Examples:

- NIGMS 'Implantable Sensor for Transplant Tissue Monitoring'

- NHLBI 'Pediatric Cardiac Monitor for Extracorporeal Life Support'

- NINDS 'Development and Early Clinical Evaluation of Noninvasive MRI Measurement of ICP ‘ 


\section{R01 Percentiled Applications \\ Cumulative Count at Each Percentile January Councils (2009-2012)}

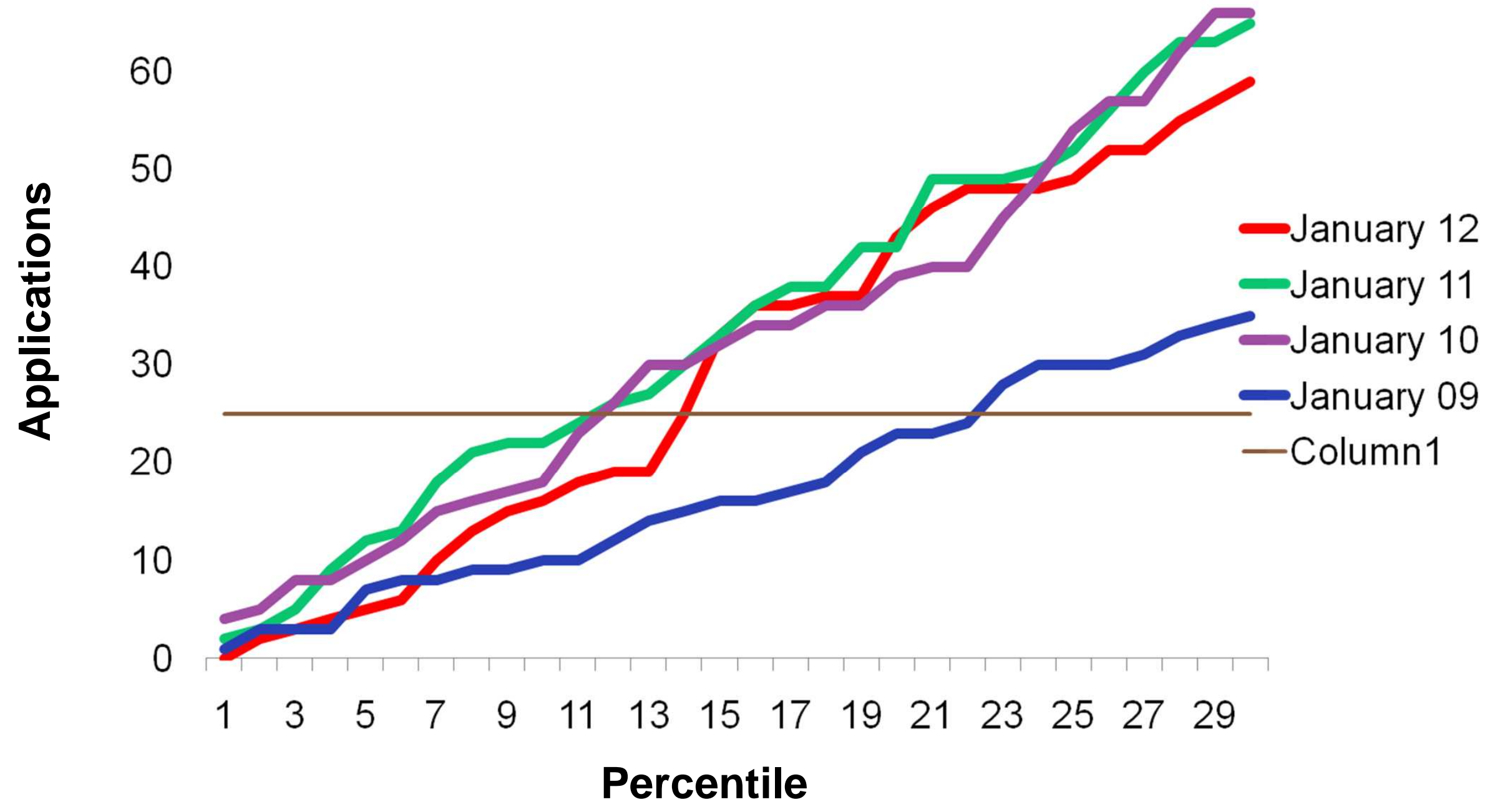




\section{SBIR/STTR Program Reauthorization}

Signed December 31, 2011

- Reauthorizes the SBIR/STTR programs for 6 years through FY 2017

- Most significant change to programs since their inception

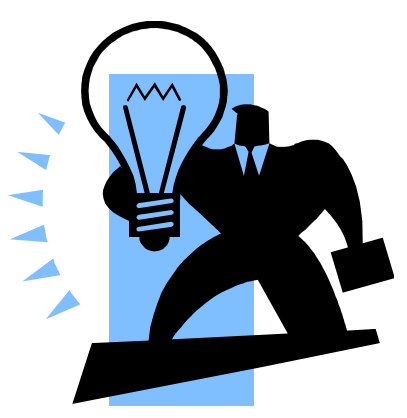




\section{Key Reauthorization Provisions}

1. Set aside requirements for Agencies will increase

\begin{tabular}{|l|c|c|}
\hline FY & Set-aside SBIR & Set-aside STTR \\
\hline 2011 (current) & $2.5 \%$ & $0.30 \%$ \\
\hline 2012 & $2.6 \%$ & $0.35 \%$ \\
\hline 2013 & $2.7 \%$ & $0.35 \%$ \\
\hline 2014 & $2.8 \%$ & $0.40 \%$ \\
\hline 2015 & $2.9 \%$ & $0.40 \%$ \\
\hline 2016 & $3.0 \%$ & $0.45 \%$ \\
\hline 2017 & $3.2 \%$ & $0.45 \%$ \\
\hline
\end{tabular}




\section{Key Reauthorization Provisions}

2. Guidelines for Size of Awards

\begin{tabular}{|l|l|l|l|} 
Program & Phase I & Phase II & Current \\
\hline SBIR & $\$ 150,000$ & $\$ 1,000,000$ & $150 \mathrm{~K} / 1 \mathrm{M}$ \\
\hline STTR & $\$ 150,000$ & $\$ 1,000,000$ & $100 \mathrm{~K} / 750 \mathrm{~K}$
\end{tabular}

3. Hard Limits* ${ }^{*}$ on award size to $50 \%$ over guidelines

\begin{tabular}{|l|l|l|l|}
\hline Program & Phase I & Phase II & Current \\
\hline SBIR & $\$ 225,000$ & $\$ 1,500,000$ & Flexible \\
\hline STTR & $\$ 225,000$ & $\$ 1,500,000$ & Flexible
\end{tabular}

* Waiver possible for Specific Topics from Sm Buss Adm 


\section{Key Reauthorization Provisions}

4. Venture Capital Participation expanded up to $25 \%$ (other agencies $15 \%$ ) of SBIR funds to SBCs majority owned by multiple VCs, hedge funds, or private equity firms

5. Technical Assistance programs

Both SBIR and STTR increased to $\$ 5,000$ per Phase I and II award per year (previously limited to SBIR-only $\$ 4,000)$ 


\section{Who are you going to call?}

- Web based information

- Scientific program staff at research institutes and centers 
tfolio Online Report...

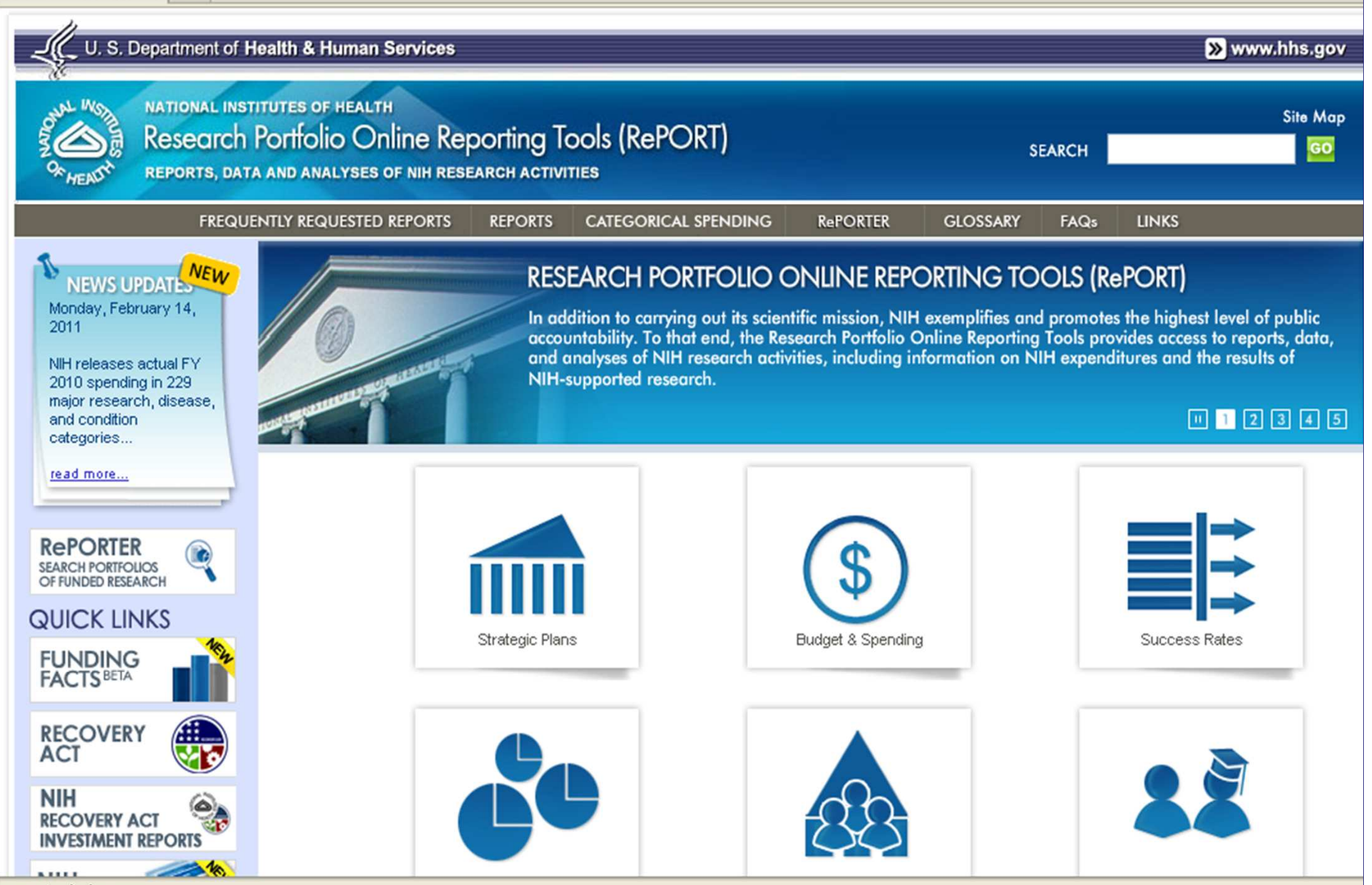




\section{What Does NIH Already Support in My Interest Area?}

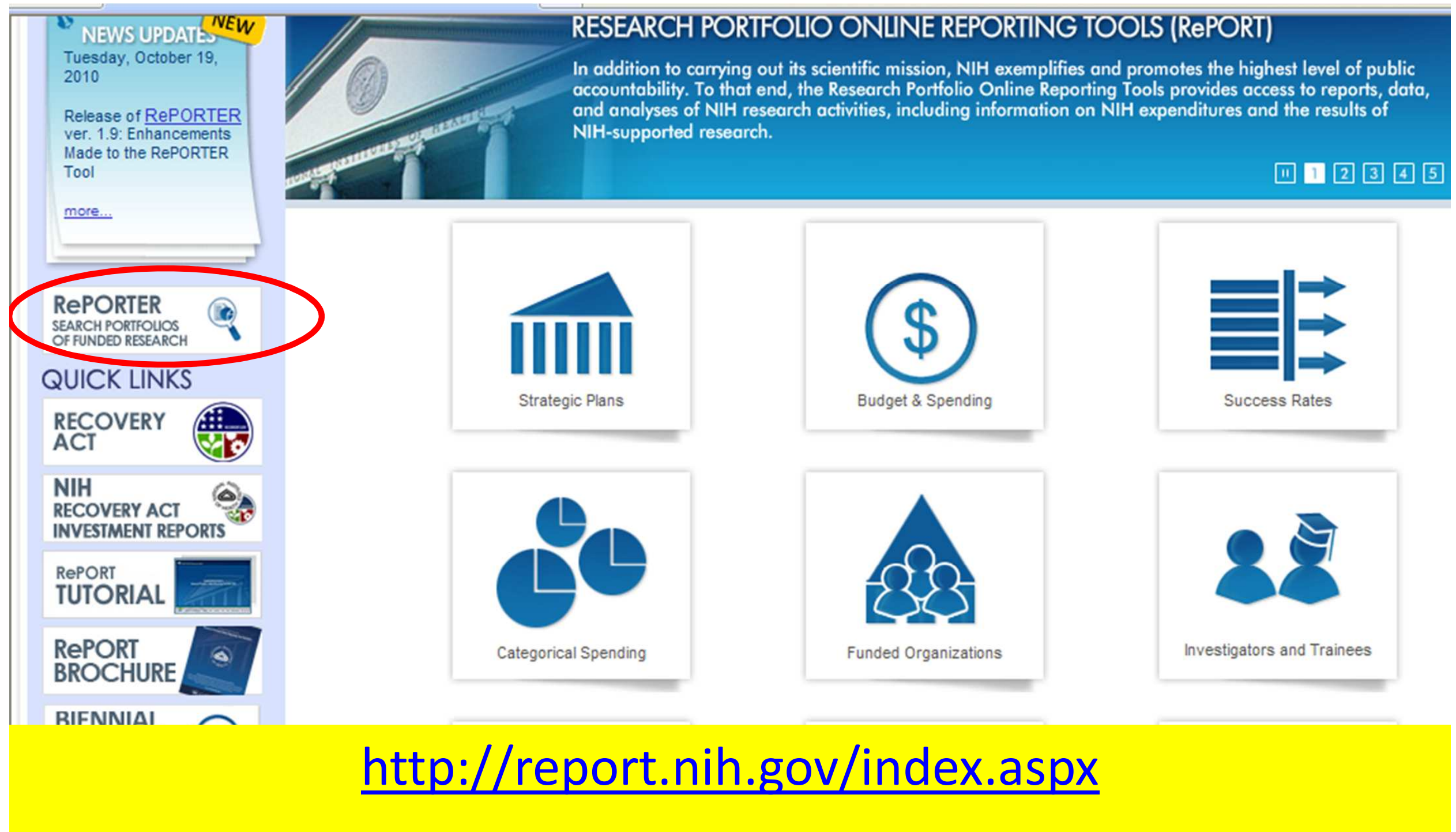




\section{NIH Searchable Databases Contain Abstracts of All Funded Projects}

Research Portfolio Online Reporting Tools (RePORT)

REPORTS, DATA AND ANALYSES OF NIH RESEARCH ACTIVITES

$$
\text { HOME FREQUENTLY REQUESTED REPORTS }
$$

REPORTS

CATEGORICAL SPEN

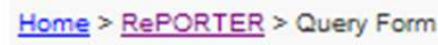

\section{(3) $\mathrm{NIH}$ RePORTER}

10/19/10 Release Note: New enhancements now available. View Release Notes for more information.

\section{SUBMII QUERY}

(?) NIH Recovery Act Projects:

? Term Search: Logic: $\bullet$ And $C$ Or

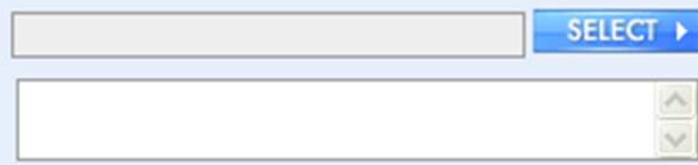

Hint: Multiple terms are accepted. Separate each term with a space. You may also use terms in " " (double quotes) for exact terms match.

\section{(?) Project Title:}

(?) Project Number: Format: 5R01CA121298-04

? Principal Investigator: (Last Name, First Name)

?) Organization:

(?) DUNS Number:

(?) Department:

? Educational Institution Type:

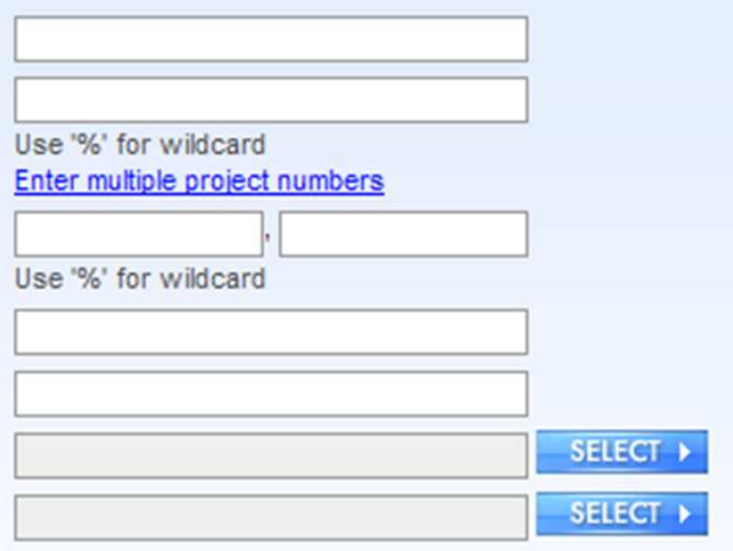

Search by

2. Skip Navi » www.hhs.go

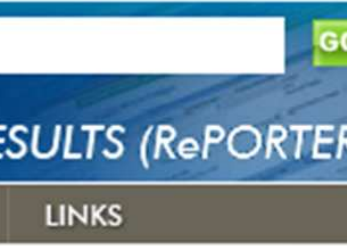

I Register Font Size: -

- Key words

- Organizations

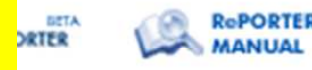

\section{States}

(?) Fisı

? $\mathrm{NIH}$

( As: Mechanisms

(1) fur Solicitations

? Aw

Q Act I Institutes

(1) st Investigators

? RFA

For
or $P$

? Puk

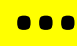


File É Edit Yiew History Bookmarks Iools Help

The National Institute of Biomedical Imaging ... +

Leading the Development and Accelerating the Application of Biomedical Technologies to Improve Health

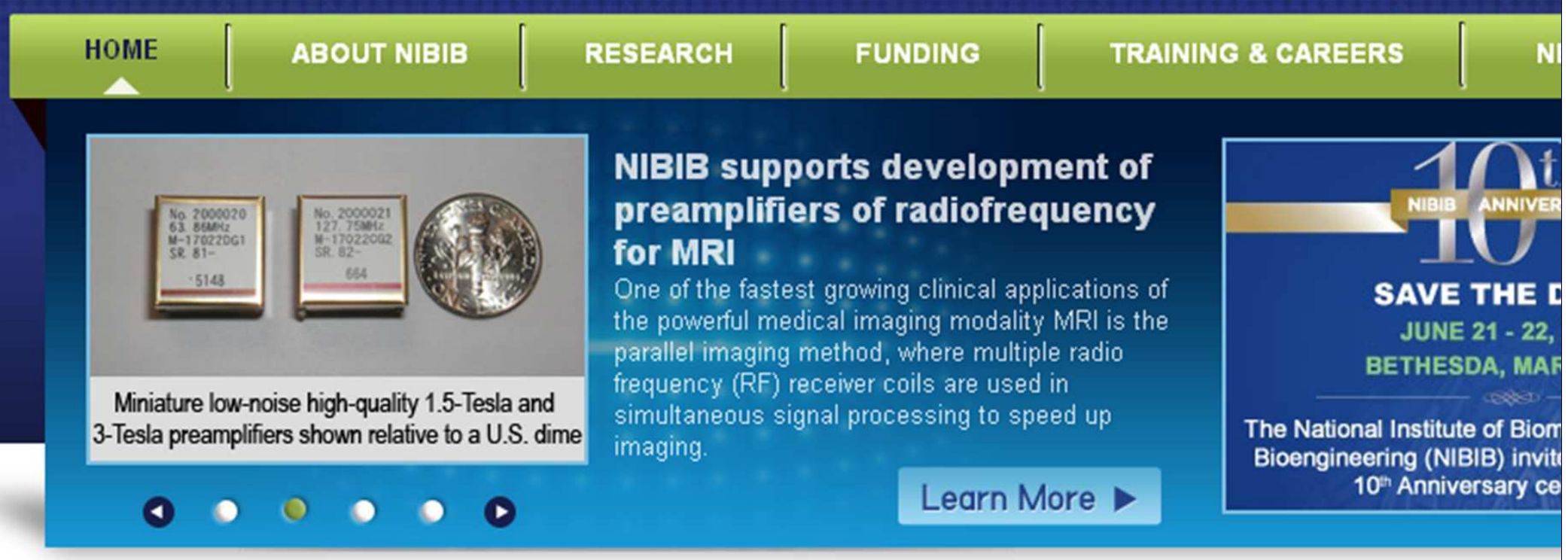


$N B B B$

National Institutes of Health

Leading the Development and Accelerating the Application of Biomedical Technologies to Improve Health

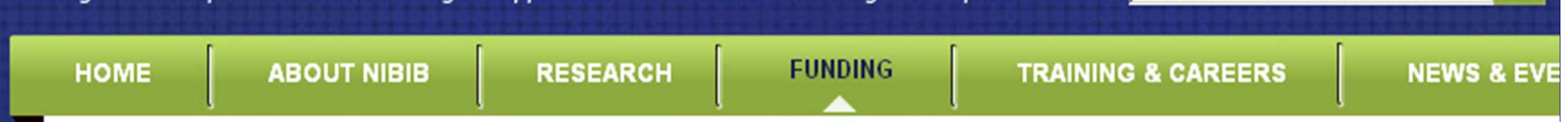

\section{Funding}

+ Grant Application Process

+ Policies for Researchers

Funding Strategies \& Policies

SIGN UP FOR OUR LISTSERV
Home > Funding Opportunities

\section{FUNDING OPPORTUNITIES}

\section{Funding Opportunities}

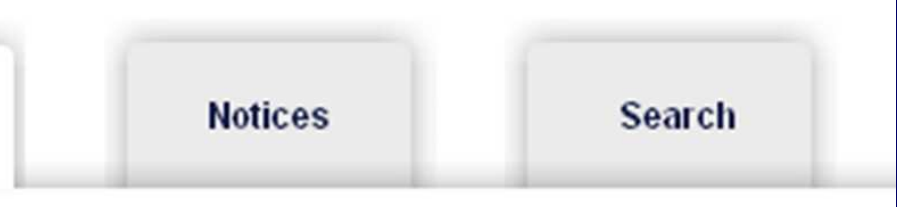

NIBIB Research Education Programs for Residents and Clinical Fellows (R25)

PAR-12-085 Posted:01/27/2012 • Expires:05/24/2014

Predictive Multiscale Models for Biomedical, Biological, Behavioral, Environmental and Clinical Research (Interage U01)

PAR-11-203 Posted:04/15/2011 Expires:02/01/2014

Nanoscience and Nanotechnology in Biology and Medicine (R01) PA-11-148, Posted:03/4/2011 Expires:05/08/2014

Nanoscience and Nanotechnology in Biology and Medicine (R21) PA-11-149, Posted:03/14/2011 Expires:05/08/2014

Indo-US Collaborative Program on Low-Cost Medical Devices (R03) PAR-11-044 Posted:11/23/2010 Expires:01/25/2013

Technologies for Healthy Independent Living (R01) PAR-11-020, Posted:11/05/2010 \& Expires:09/20/2013

Design and Development of Novel Technologies for Healthy Independent Living (R21) PAR-11-021 Posted:11/05/2010 4 Expires:09/20/2013

Bioengineering Research Partnerships (BRP)[R01] PAR-10-234 Posted:07/21/2010, Expires:09/08/2013 


\section{Research}

\section{Labs At NIBIB (Intramural)}

Scientific Program Areas (Extramural)

Biomedical Technology Resource Centers

\section{Quantum Grants}

Resources for Researchers

SIGN UP FOR OUR LISTSERV

BRSS
Home > Research > Scientific Program Areas (Extramural)

\section{Scientific Program Areas (Extramural)}

NIBIB is the newest of the NIH research Institutes and Centers. It was established to provide a research home for the development and application of new technologies and techniques for the delivery of health care in the 21 st century. It brings together the research communities of biomedical imaging, bioengineering, the physical sciences and the life sciences to advance human health by improving quality of life and reducing the burden of disease.

Learn more about the mission and history of NIBIB.

Learn about the NIBIB research program areas, including descriptions, staff contacts, relevant programs and study sections:

> Biomaterials

$>$ Biomedical Informatics

> Drug and Gene Delivery Systems and Devices

$>$ Image-Guided Interventions

> Image Processing, Visual Perception and Display

> Magnetic, Biomagnetic and Bioelectric Devices

> Magnetic Resonance Imaging and Spectroscopy

> Mathematical Modeling. Simulation and Analysis

> Interagency Modeling and Analysis Group (IMAG)

> Medical Devices and Implant Science

$>$ Micro-Biomechanics

> Micro- and Nano-Systems; Platform Technologies

$>$ Molecular Imaging 
3) The National Institute of Biomedical Imaging and Bioengineering (NIBIB) - Mozilla Firefox

Eile Edit View History Bookmarks Iools Help

(1) - C X \& $\square$ http://www.nibib.nih.gov/About/Directories/ProgramStaff/McLaughlin

8.- Google

D. Most Visited $\square$ POTS 9 ITAS $\square$ HelpDesk $\square$ SharePoint $\square$ NIH QVR

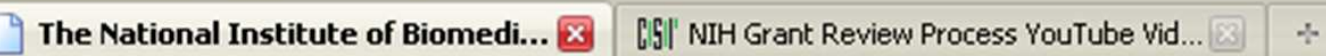

HOME $\mid$ ABOUT NIBIB $\lceil$ RESEARCH $\mid$ FUNDING $\mid$ TRAINING \& GAREERS $\mid$ NEWS \& EVENTS

\section{About NIBIB}

\section{+ Overview}

+ Mission \& History

\section{Strategic Plans}

Budget \& Legislation

NIBIB Advisory Council

+ Staff Directories

Visitor Information

Careers

SIGN UP FOR OUR LISTSERV

Home $>$ About NIBIB $>$ Staff Directories $>$ Scientific Program Staff Directory $>$ Staff Page: Alan McLaughlin

Alan McLaughlin, Ph.D.

\section{Director}

Division of Applied Science and Technology

Democracy Plaza II, Suite 200

Tel: $301-496-9321$

Fax: 301-480-1614

E-mail: mclaugal@mail.nih.gov

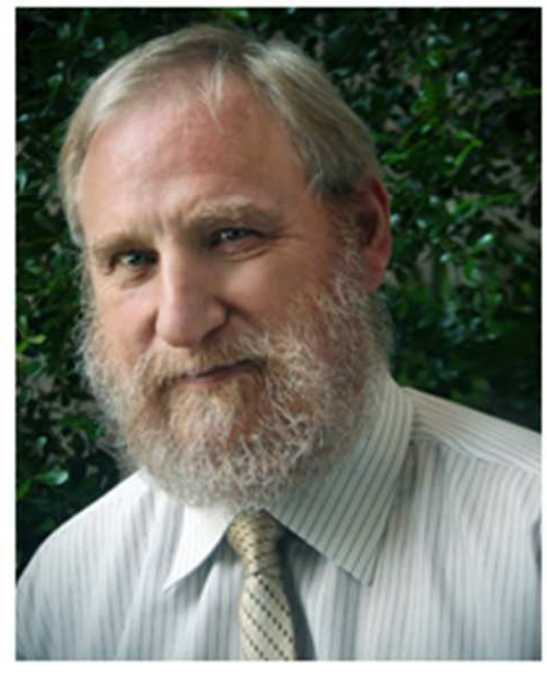

\section{Research Expertise}

Dr. Alan McLaughlin is the Director of the Division of Applied Science and Technology at the NIBIB. With a background in physics, biophysics, and physiology, his portfolio includes magnetic resonance imaging (MRI) and magnetic resonance spectroscopy (MRS). He completed a post-doctoral fellowship in the Biochemistry Department at Oxford University, and subsequently held 
(3) NIH Grant Review Process YouTube Videos - Mozilla Firefox

Eile Edit View Hiștory Bookmarks Iools Help

C $\mathrm{C}$ [ISI' http://cms.csr.nih.gov/ResourcesforApplicants/InsidetheNIHGrantReviewProcessVideo.htm

$\hat{\omega} \cdot \mathbf{3}$ - Google

D. Most Visited $\square$ POTS 9 ITAS $\square$ HelpDesk $\square$ SharePoint $\square$ NIH QUR 9 Audio-Digest Foundati...

The National Institute of Biomedical Im..

[ISI' NIH Grant Review Process YouTu... $x$

national institutes of health

thome contact csr 1 staff directory

$10 \mid{ }^{\circ}$ center for

scientific review

search Enter keyword(s)

Home $>$ Resources for Applicants

NIH Grant Review Process YouTube Videos

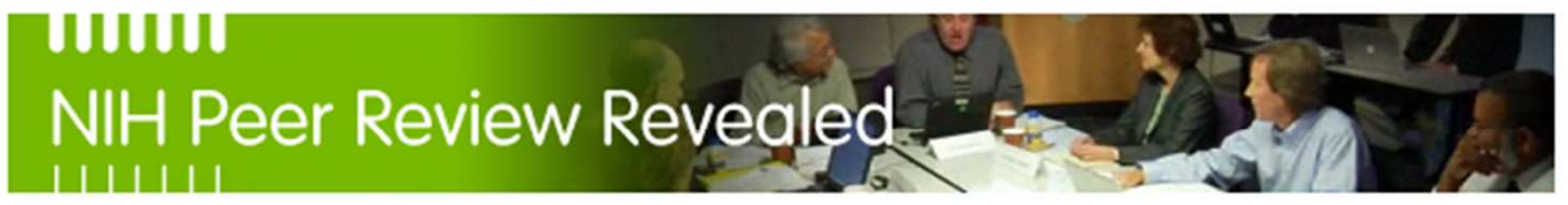

CSR has produced a series of videos to give you an inside look at how scientists from across the country review NIH grant applications for scientific and technical merit.

New and established applicants will find insights and understanding that can empower them to improve the applications and increase their chances for receiving a more positive review.
$\Theta$ printer friendly

\section{Home}

- about CSR

- News and Reports

- Peer Review Meetings

- Resources for Applicants

\begin{tabular}{|l|l|l|l|}
\hline $\begin{array}{l}\text { NIH Peer Review Revealed } \\
\text { Provides a front-row seat to a } \\
\text { review peer review meeting. }\end{array}$ & $\begin{array}{l}\text { NIH Tips for Applicants } \\
\text { Gives applicants practical } \\
\text { advice and insights. }\end{array}$ & $\begin{array}{l}\text { What Happens to Your NIH } \\
\text { Grant Application shows our } \\
\text { popular outreach talk. }\end{array}$ \\
\hline NIH Peer Review & NIH Tips for sppl & \\
\hline
\end{tabular}




\section{You Tube NIH Peer Review Revealed...}

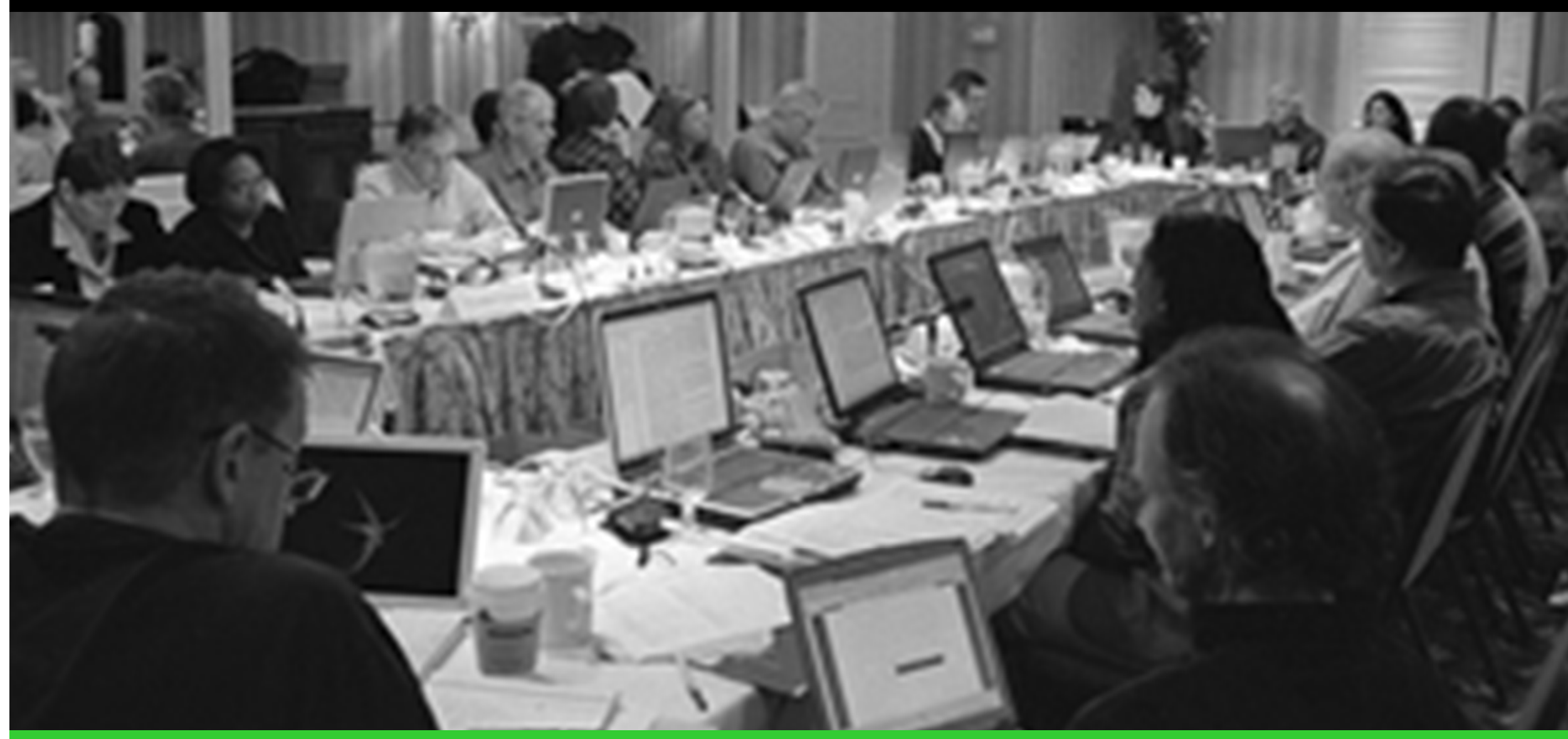

national institutes of health

| $\mid \begin{aligned} & \text { center for } \\ & \text { scientific review }\end{aligned}$
http://cms.csr.nih.gov/ResourcesforApplicants/ InsidetheNIHGrantReviewProcessVideo.htm 


\section{Peer Review and You}

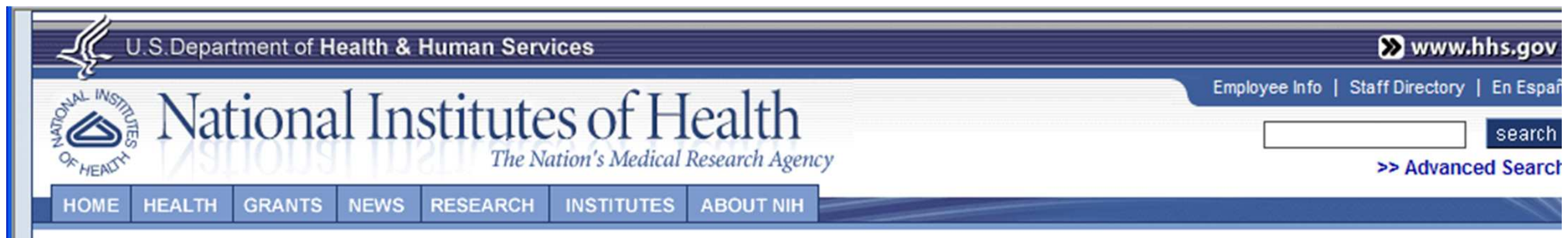

Peer Review Home

Email this pagt

\section{Enhancing Peer Review at NIH}

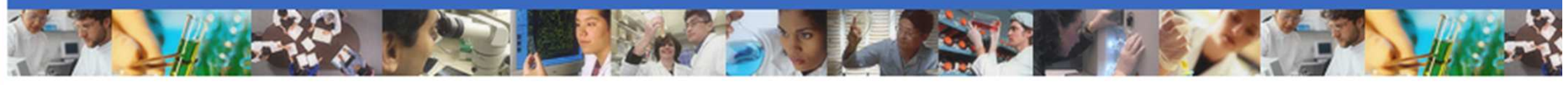

Peer Review Home

Implementation Goals

$>$ Engage the Best

Reviewers

Improve the Quality \& Transparency of Review

Ensure Balanced and Fair Reviews

Continuous Review of Peer Review

Policy Announcements

\section{Overview}

The National Institutes of Health $(\mathrm{NIH})$ has a longstanding history of supporting the most promising and meritorious research. The increasing breadth, complexity, and interdisciplinary nature of modern research has necessitated a more formal review of the $\mathrm{NIH}$ peer review system. In March 2008, the $\mathrm{NIH}$ announced the end of a year-long diagnostic phase and release of the final report. The report identified the most significant challenges and proposed recommendations that would enhance the peer review system.

Fund the best science, by the best scientists, with the least amount of administrative burden.

Phases of Process
Read about shortened and restructured

application forms and instructions.

\footnotetext{
Latest News

- Application Changes Announced (9/16/09)

- Need Help Interpreting the New Review Scores? (PDF - 292 KB)

- Overview of Enhancements with a Focus on Applicants (PDF - 125 KB)

- Overview of Enhancements with a Focus on
}

\section{http://enhancing-peer-review.nih.gov/index.html}




\section{Summary}

- Lots of help is available from web sites and also to program directors

- NIBIB is the tip of the bioengineeering iceberg at $\mathrm{NIH}$, consider us first but not exclusively

- Funding is available at all career stages and at many levels

- About $85 \%$ of NIH funds go out to the community 